\title{
CONTRACTION OF CORPORATE LENDING ${ }^{1}$
}

\author{
M.Khromov
}

In 2015, the volume of loans extended by banks to enterprises and organizations drastically declined. The volume of new loans granted during the year plummeted, while the amount of debt owed to the banking sector by corporate borrowers remained practically unchanged. The decline rate of credit extended to big businesses was lower than the overall median, and the quality of their accounts payable was higher than the average, while the small and medium-sized business borrowers that had shown a considerable laxity of repayment discipline were much less able to secure bank loans.

In 2015, the credit market for corporate borrowers significantly contracted. The volume of ruble-denominated loans extended to corporate borrowers dropped by $9.8 \%$ relative to 2014 - from $\mathrm{Rb} 33.2$ trillion to $\mathrm{Rb} 30.0$ trillion. The volume of loans granted in the forex segment of the market simply plummeted: the volume of new loans extended to corporate borrowers dropped almost twofold relative to the previous year: $\$ 68.6 \mathrm{bn}$ in $2015 \mathrm{vs}$. $\$ 134.5 \mathrm{bn}$ in 2014 .

Despite a significant decline in new loans extended to corporate borrowers, the amount of their ruble-denominated debt to the banking sector increase by a mere $1.1 \%$ over the course of 2015 . A similar situation was seen in relation to forex loans. The two-fold drop in new loans resulted only in a small (2.7\%) decline of corporate debt in US dollar terms. The aforementioned change in the ratio between the amount of corporate debt and the amount of new loans can apparently be explained by a considerable increase in the loan period. During 2015, the share of loans with the repayment period exceeding three years in the total amount of debt accumulated by nonfinancial organizations increased from $47 \%$ to $51 \%$.

The slowdown in the growth rate of loans extended to the economy in the year 2015 was accompanied by a notable deterioration in the quality of debt servicing on the part of corporate borrowers. The amount of their overdue accounts payable increased at an accelerated pace: the volume of overdue rubledenominated loans grew almost 1.5fold (by $48.6 \%$ ), while the volume of overdue forex loans rose by $80 \%$. As a result, over the course of 2015, the share of overdue ruble-denominated loans increased from $5.0 \%$ to $8.8 \%$, while the share of forex loans increased from $2.1 \%$ to $3.8 \%$. At the

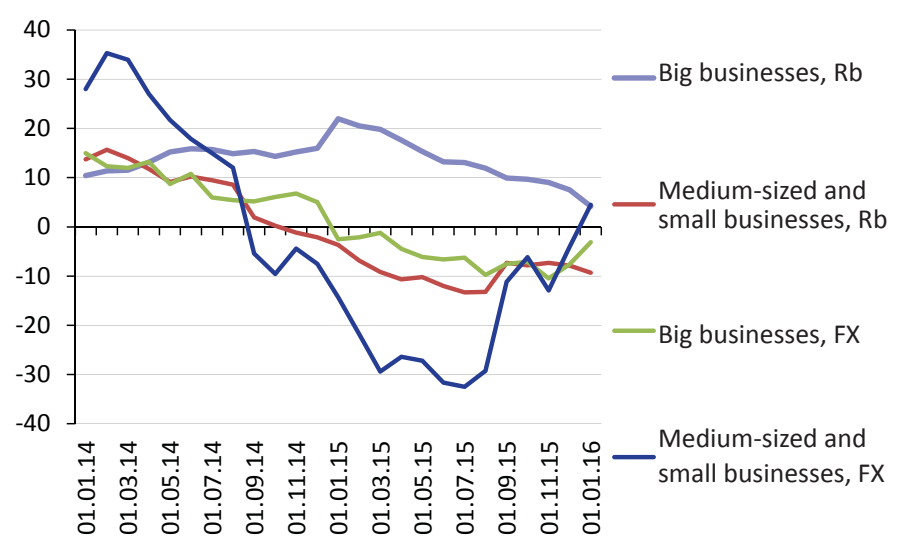

Source: Bank of Russia.

Fig. 1. The growth rate of credit extended to corporate borrowers relative to the corresponding date of previous year, $\%$

1 This paper was originally published in Online Monitoring of Russia's Economic Outlook No. 5(23). 
same time, the quality of forex loans remained much better than that of ruble-denominated loans.

As far as the size of a borrower business is concerned, it should be said that the slowdown in the growth rate of loans extended to corporate borrowers mainly affected small and medium-sized businesses. Thus, in the ruble segment of the credit market for corporate borrowers, the amount of credit extended to big businesses dropped only by $5 \%$, while the amount of loans extended to small and medium-sized businesses - by $30 \%$. The slowdown in the growth rate of loans extended to individual entrepreneurs was even more pronounced: the amount of loans extended to them in 2015 dropped almost two-fold relative to 2014.

Quite naturally, the aforesaid dynamics of new-loan lending resulted in a change in accounts payable. As far as big businesses, small businesses and individual entrepreneurs are concerned, their accounts payable to banks declined, over the course of 2015 , by $4 \%, 10 \%$ and $27 \%$ respectively.

The situation in the forex segment of the credit market for corporate borrowers was slightly different. Firstly, there was a considerable fall in the amount of loans extended to all categories of borrowers. Secondly, the performance of medium-sized and small businesses with respect to borrowing from banks $(-41 \%)$ was only slightly better than that of big businesses $(-50 \%)$. Correspondingly, the dynamics of forex-denominated accounts payable of big businesses and all the other businesses was the direct opposite of the dynamics of ruble-denominated credit extended thereto. Big businesses reduced their forex-denominated debt to banks by $3.1 \%$, while small and medium-sized businesses, on the contrary, increased theirs by $4.5 \%$.

As shown by the results of the year 2015 , the traditional observation regarding the quality of loans held true: the bigger the borrower, the better its debt was served. This observation held true both with regard to the ruble and forex segments of the credit market for corporate borrowers, as well as to the dynamics of overdue loans. The share of overdue loans extended to big businesses grew the least and remained lower than the share of overdue loans (both ruble-denominated and forex-denominated) extended to medium-sized and small businesses. Thus, over the course of 2015, the share of overdue loans extended to large corporate clients increased by a mere $1.6-1.7$ p.p. By the beginning of 2016, the share of rubledenominated loans extended thereto had risen to $6.4 \%$, while that of forex loans - to $3.7 \%$. The rise in the share of forex loans extended to small and medium-sized businesses was approximately the same: by +2.1 p.p., to $5.9 \%$ as of the beginning of 2016. At the same time, the quality of ruble-denominated loans extended to small and medium-sized businesses considerably decreased: over the course of 2015, the share of overdue ruble-denominated loans increased by almost 7 p.p., to $15.4 \%$.

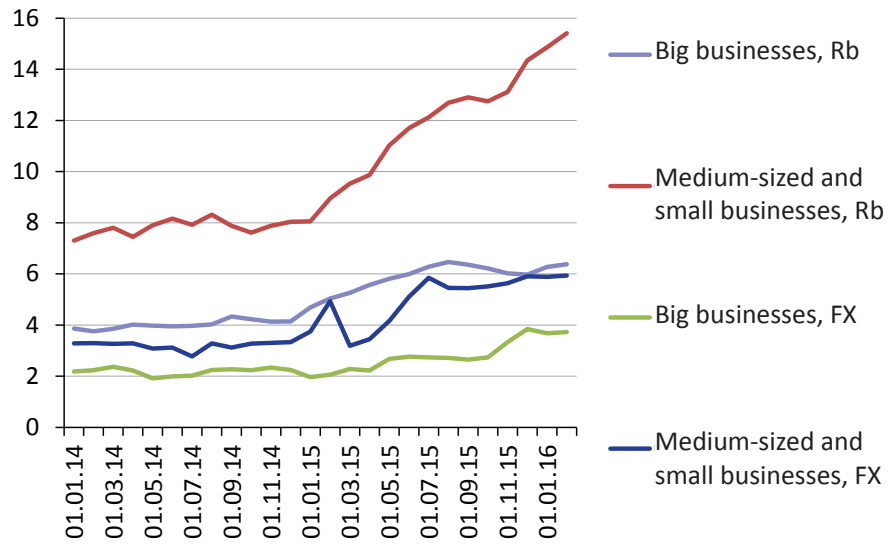

Source: Bank of Russia.

Fig. 2. The share of overdue loans extended by banks to their corporate clients, $\%$ 


\section{THE MAIN PARAMETERS OF BANK LOANS EXTENDED TO VARIOUS BRANCHES OF THE ECONOMY IN 2015}

\begin{tabular}{|c|c|c|c|c|c|c|}
\hline & \multicolumn{3}{|c|}{ Ruble-denominated loans } & \multicolumn{3}{|c|}{ Forex-denominated loans * } \\
\hline & 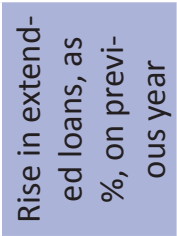 & 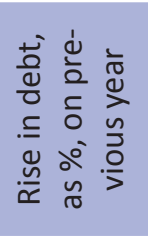 & 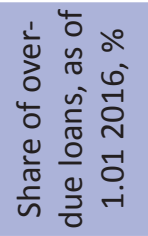 & 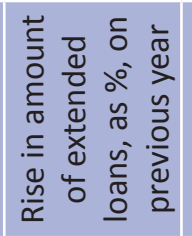 & 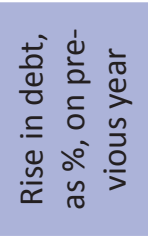 & 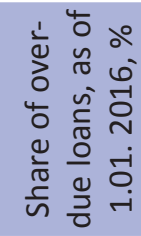 \\
\hline Total & -9.8 & 1.1 & 8.0 & -49.5 & -2.7 & 3.8 \\
\hline mineral extraction & -21.9 & 9.0 & 2.1 & -44.4 & 0.8 & 6.0 \\
\hline processing industries & 37.4 & 13.2 & 5.9 & -47.8 & -10.0 & 2.2 \\
\hline $\begin{array}{l}\text { production of food com- } \\
\text { modities, including bever- } \\
\text { ages and tobacco products }\end{array}$ & 83.3 & 8.7 & 8.5 & -34.8 & -5.8 & 1.1 \\
\hline $\begin{array}{l}\text { timber processing \& wooden } \\
\text { product manufacturing }\end{array}$ & -28.5 & -3.0 & 12.6 & -73.6 & -5.8 & 1.0 \\
\hline $\begin{array}{l}\text { pulp \& paper produc- } \\
\text { tion; publishing activity }\end{array}$ & 42.5 & 27.3 & 13.2 & 50.5 & -15.6 & 2.3 \\
\hline $\begin{array}{l}\text { production of coke, } \\
\text { petrochemicals and } \\
\text { nuclear materials }\end{array}$ & 127.4 & 99.7 & 3.4 & -47.6 & -5.5 & 0.8 \\
\hline chemical production & -3.7 & 8.5 & 3.6 & -84.5 & -27.5 & 0.5 \\
\hline $\begin{array}{l}\text { manufacturing of other non- } \\
\text { metallic mineral products }\end{array}$ & -9.1 & 10.6 & 7.2 & -43.4 & 4.4 & 17.9 \\
\hline $\begin{array}{l}\text { metallurgical production } \\
\& \text { manufacturing of fin- } \\
\text { ished metal products }\end{array}$ & 3.5 & 32.7 & 6.7 & -19.9 & 16.0 & 0.3 \\
\hline $\begin{array}{l}\text { manufacturing of machin- } \\
\text { ery \& equipment }\end{array}$ & -16.7 & 4.0 & 5.3 & -69.6 & -33.0 & 14.0 \\
\hline $\begin{array}{l}\text { manufacturing of means } \\
\text { of transportation \& } \\
\text { transport equipment }\end{array}$ & -7.0 & 6.9 & 1.8 & -27.6 & -18.5 & 1.8 \\
\hline $\begin{array}{l}\text { production \& distribution of } \\
\text { electrical energy, gas \& water }\end{array}$ & -16.0 & 6.8 & 2.2 & -71.4 & 0.6 & 0.0 \\
\hline $\begin{array}{l}\text { agriculture, hunt- } \\
\text { ing \& forestry }\end{array}$ & 11.6 & 5.0 & 9.9 & -50.9 & -28.9 & 23.2 \\
\hline building construction & -32.7 & -12.4 & 22.4 & -56.0 & -12.9 & 3.4 \\
\hline transport \& communication & -5.1 & -6.2 & 6.6 & -45.5 & -9.6 & 5.0 \\
\hline $\begin{array}{l}\text { wholesale \& retail trade; } \\
\text { repair of passenger-carrying } \\
\text { vehicles, motorcycles, home } \\
\& \text { kitchen appliances \& } \\
\text { personal demand items }\end{array}$ & -23.3 & -17.3 & 10.9 & -40.8 & -4.2 & 5.7 \\
\hline $\begin{array}{l}\text { transactions with real } \\
\text { estate; lease of property } \\
\& \text { rendering of services }\end{array}$ & -4.3 & 13.5 & 5.7 & -48.8 & -1.1 & 3.8 \\
\hline other types of activity & -12.4 & 8.0 & 5.9 & -58.3 & 17.6 & 2.2 \\
\hline
\end{tabular}

ther types of activity

$-12.4$

are calculated in US dollars.

* The growth rates of for

In 2015, the progress of bank lending to businesses involved in various types of economic activity was multidirectional. In the ruble segment of the credit market for corporate borrowers, there was a rise in the volume of 
loans extended to agricultural enterprises (by $12 \%$ relative to 2014 ) and to a wide range of processing industries. The largest recipients of loans from the banking sector that were mainly responsible for loan growth in 2015 were oil-refining enterprises $(+127 \%)$; food industry enterprises $(+83 \%$ relative to 2014); and pulp \& paper and publishing enterprises (+42\%). These industries also showed a significant rise in their ruble-denominated accounts payable to banks.

The greatest decline in the volume of bank lending extension was in the construction sector (a 33\% drop in the volume of extended loans and a 12\% drop in the volume of debt) and commerce (a $23 \%$ drop in the volume of new loans and a $17 \%$ drop in ruble-denominated debt).

The dependence of the lending market's behavior on the quality of loans was evident only with regard to those industries where the volume of bank loans issued to businesses was on the decline. The construction sector reached a record high in its volume of overdue debt, which amounted to $22 \%$ of the total volume of ruble-denominated loans extended thereto. The share of overdue loans in the total amount of loans extended to commercial enterprises is also higher than their average share with regard to all borrowers ( $11 \%$ vs. $8 \%)$.

Borrowers with low credit scores were also able to receive bank loans. Thus, while the quality of loan servicing remained high and the share of overdue debt amounted to a mere $3 \%$, the quality of the loan portfolio of borrowers in the food industry was merely adequate (8.5\%). 